\title{
O LAZER NAS CONFERÊNCIAS E NOS PLANOS NACIONAIS DE POLÍTICAS PARA AS MULHERES ${ }^{1}$
}

Recebido em: 05/07/2019

Aprovado em: 10/11/2019

Licença: @) (1) @

Claudia Regina Bonalume ${ }^{2}$

Hélder Ferreira Isayama

Universidade Federal de Minas Gerais (UFMG)

Belo Horizonte $-\mathrm{MG}-$ Brasil

\begin{abstract}
RESUMO: Neste artigo trazemos uma análise acerca da relação mulheres e lazer, presente nas conferências e nos planos nacionais de políticas para as mulheres. Até o momento, as cinco conferências nacionais e os três planos delas derivados nos permitem perceber que a temática do lazer se faz timidamente presente nas demandas, quase restrita às situações em que um rol de direitos é reivindicado. No entanto, a participação dos órgãos governamentais responsáveis por políticas que envolvem lazer na elaboração dos planos, a exemplo dos ministérios da Cultura e do Esporte, interfere no resultado, favorecendo a inclusão da temática. O lazer, quando mencionado, é tratado como vivência significativa, humanizada, integrada e contextualizada, sem ênfase ao viés compensatório. Embora não esteja invisível, é possível perceber que esse direito social ainda é pouco demandado pelo segmento mulheres.
\end{abstract}

PALAVRAS-CHAVE: Atividades de Lazer. Mulheres. Conferências.

\section{LEISURE AT CONFERENCES AND NATIONAL POLICY PLANS FOR WOMEN}

ABSTRACT: In this article we present an analysis about the relationship between women and leisure in the national conferences and polity plans for women. Until now, the five national conferences and three plans derived from them allow us to realize that the theme of leisure is timidly present in the demands, almost restricted to the situations in which a list of rights is claimed. However, the participation of government agencies responsible for policies that involve leisure in the elaboration of plans, like de Ministries of Culture and Sports, interferes in the result, favoring the inclusion of the theme. Leisure, when mentioned, is treated as a meaningful, humanized, integrated and contextualized

\footnotetext{
${ }^{1}$ Artigo premiado no $30^{\circ}$ Encontro Nacional de Recreação e Lazer (ENAREL), realizado em Curitiba/PR em 2019.

${ }^{2}$ Doutoranda do Programa de Pós-Graduação Interdisciplinar em Estudos do lazer da UFMG. Pesquisadora do Oricolé - Laboratório de Pesquisa sobre Formação e Atuação Profissional no Lazer da UFMG.

${ }^{3}$ Docente da Universidade Federal de Minas Gerais e do Programa de Pós-Graduação Interdisciplinar em Estudos do Lazer. Líder do Oricolé - Laboratório de Pesquisa sobre Formação e Atuação Profissional no Lazer.
} 
experience, without emphasis on the compensatory bias. Although not invisible, it is possible perceive that this social right is still little demanded by the women segment.

KEYWORDS: Leisure Activities. Women. Conferences.

\section{Introdução}

Ao trazermos uma abordagem que envolve o lazer e as mulheres, estamos direcionando a reflexão ao segmento social que contempla mais de metade da população brasileira, com especificidades, histórias, conquistas, preocupações, lutas e anseios, diversificados, considerando atravessamentos identitários como classe, raça, profissão e idade. Essas especificidades, características e questões são pertinentes, também, à relação entre as mulheres e o lazer. Apesar de diversas temáticas feministas já terem avançado significativamente, Pedro (2018) chama atenção para a invisibilidade ideológica presente em alguns campos da vida das mulheres, entre os quais nos interessa saber se está o lazer.

Conceder direitos à mulher, enquanto mais um segmento social, considerado de maneira abstrata e ideal, certamente é mais simples do que pensá-lo para as mulheres com vidas cotidianas repletas de especificidades de demandas ainda latentes, frutos da cultura de uma sociedade de classes, organizada sobre bases que têm como norma e como modelo o masculino. Enfrentar esse cenário demanda vontade política, amparo legal e, principalmente, mudança de modelos, hábitos, mentalidades e culturas.

Buscar uma aproximação com a parte desse cenário que diz respeito à relação das mulheres com o direito social ao lazer é o desafio que assumimos para este texto. Com vistas a fazer frente a esse desafio recorremos aos documentos finais, publicações e/ou anais referentes às conferências nacionais de políticas para as mulheres (CNPM) e aos planos nacionais de políticas para as mulheres (PNPM). O intuito foi identificar e analisar as relações estabelecidas entre o lazer e as mulheres, nas reivindicações e planos de ações voltadas a elas nos documentos. 
O material analisado abrange a Conferência Nacional de Mulheres Brasileiras, realizada em 2002 por movimentos feministas, sem envolvimento do Governo Federal, as quatro edições seguintes das conferências, realizadas pela Secretaria Especial de Políticas para Mulheres (SPM) em parceria com o Conselho Nacional dos Direitos da Mulher (CNDM), em 2004, 2007, 2011 e 2016 e os três planos gerados a partir delas ${ }^{4}$.

O texto constitucional, vigente desde 1988, prevê as vias da representação e da participação como formas de expressão da soberania popular e Avritzer (2012) ressalta que as conferências nacionais fortalecem o marco participativo previsto na Constituição. Segundo o autor, a prática desse mecanismo ganhou ênfase no Brasil a partir de 2003, com a expansão das conferências nos governos do Partido dos Trabalhadores, estreitando a aproximação entre governo e sociedade civil organizada.

Abers; Serafim; Tabagira (2014) destacam que esta proximidade contribuiu para a criação de padrões históricos de interação Estado-sociedade, o que elas denominam repertórios de interação. Para a construção desses repertórios, os movimentos sociais investiram em ações com e por dentro do Estado e a participação institucionalizada foi uma das estratégias que se constituiu em formas acordadas e negociadas, a exemplo dos conselhos e das conferências.

Neste cenário, a criação da Secretaria Especial de Políticas para as Mulheres, em 2003, favoreceu a institucionalização da proposta de políticas para esse segmento. Segundo AMB (2011), isso permitiu que mais mulheres ocupassem espaços na relação com o Estado, seja pela via da participação em conselhos de direitos da mulher, seja na direção de organismos de políticas para mulheres, instituídos nos poderes executivos, ou atuando na disputa de orientação dessas políticas, no momento das conferências.

\footnotetext{
${ }^{4}$ A Conferência Nacional de Mulheres Brasileiras não teve o intuito de construir um plano. Já a IV CNPM foi realizada em 2016, durante o processo de impeachment da Presidenta Dilma Rousseff. Os governos que a sucederam não deram andamento à elaboração do respectivo Plano.
} 
Enquanto estudiosos da área, nos interessa saber se as reivindicações e propostas de políticas para as mulheres incluem o direito ao lazer, contemplado no artigo sexto da Constituição Federal entre os direitos sociais.

Lazer é um tema muito amplo que é influenciado por vários fatores como sexo, gênero, sexualidade, raça, etnia, cultura, localização geográfica, status social, habilidades físicas, entre muitos outros aspectos e circunstâncias que definem e determinam a realidade de cada um de nós. Não é possível tentar definir lazer sem considerar "lazer para quem" (BARBOSA; LIECHTY; PEDERCINI, 2013, p. 16).

Nos propomos, então, a identificar e analisar a presença, a ausência, o lugar e a concepção dados ao lazer nos documentos mencionados, bem como as transformações que ocorreram em relação à temática entre os eventos.

\section{Percurso Metodológico}

O estudo alia pesquisa bibliográfica e análise documental, procurando conhecer os objetos investigados, sua organização, pautas principais e as relações estabelecidas entre mulheres e lazer. Inicialmente realizamos uma incursão pelos documentos referentes ao processo de organização e realização de cada uma das conferências e planos com vistas a situá-los no contexto histórico e político. Na sequência, coletamos os dados referentes à relação mulheres e lazer dos materiais e realizamos uma análise qualitativa. O Quadro 1 traz uma breve síntese dos principais achados.

\section{Quadro 1: Documentos analisados e contexto de realização das conferências.}

\begin{tabular}{|c|c|c|}
\hline $\begin{array}{l}\text { Evento/período de } \\
\text { realização }\end{array}$ & Documentos analisados & $\begin{array}{c}\text { Especificidades destacadas em relação ao contexto } \\
\text { das conferências }\end{array}$ \\
\hline $\begin{array}{l}\text { Conferência } \\
\text { Nacional de } \\
\text { Mulheres } \\
\text { Brasileiras - } \\
\text { Brasília, } 6 \text { e } 7 \text { de } \\
\text { julho de } 2002 \text {. }\end{array}$ & $\begin{array}{l}\text { Carta de Princípios } \\
\text { Plataforma Política } \\
\text { Feminista (AMB, 2002). }\end{array}$ & $\begin{array}{l}\text { Convocada e realizada por dez movimentos de } \\
\text { defesa dos direitos das mulheres sob alegação de } \\
\text { omissão governamental em relação às demandas } \\
\text { do segmento. Precedida de } 26 \text { conferências } \\
\text { estaduais. }\end{array}$ \\
\hline
\end{tabular}




\begin{tabular}{|c|c|c|}
\hline $\begin{array}{l}\text { I Conferência } \\
\text { Nacional de } \\
\text { Políticas para as } \\
\text { Mulheres - } 15 \text { a } 17 \\
\text { de julho de } 2004 .\end{array}$ & $\begin{array}{l}\text { I Conferência Nacional } \\
\text { de Políticas para as } \\
\text { Mulheres (SPM, 2004); } \\
\text { Propostas de Diretrizes } \\
\text { para uma Política } \\
\text { Nacional para as } \\
\text { Mulheres (SPM, 2004). } \\
\text { Plano Nacional de } \\
\text { Políticas para as } \\
\text { Mulheres (BRASIL, } \\
\text { 2004). }\end{array}$ & $\begin{array}{l}\text { Primeira Conferência de Mulheres convocada pelo } \\
\text { Governo Federal, realizada no segundo ano de } \\
\text { mandato do Presidente Luiz Inácio Lula da Silva } \\
\text { que havia criado a SPM no ano antes. Foi precedida } \\
\text { de conferências municipais e estaduais. As } 239 \\
\text { resoluções aprovaram a natureza, os princípios e } \\
\text { diretrizes da Política Nacional para as Mulheres na } \\
\text { perspectiva da igualdade de gênero e serviram de } \\
\text { subsídio à elaboração do Plano Nacional, } \\
\text { estruturado em quatro áreas estratégicas de atuação: } \\
\text { autonomia, igualdade no mundo do trabalho e } \\
\text { cidadania; educação inclusiva e não sexista; saúde } \\
\text { das mulheres, direitos sexuais e direitos } \\
\text { reprodutivos; enfrentamento à violência contra as } \\
\text { mulheres. }\end{array}$ \\
\hline $\begin{array}{l}\text { II Conferência } \\
\text { Nacional de } \\
\text { Políticas para as } \\
\text { Mulheres, Brasília, } \\
17 \text { a 20/08/2007. }\end{array}$ & $\begin{array}{l}\text { II Conferência de } \\
\text { Políticas para as } \\
\text { Mulheres (SPM, 2013a). } \\
\text { II Plano Nacional de } \\
\text { Políticas para as } \\
\text { Mulheres (Brasil, 2008). }\end{array}$ & $\begin{array}{l}\text { A conferência seguiu as diretrizes gerais da } \\
\text { anterior, com ampliação de algumas pautas. O } \\
\text { ambiente político relatado demonstra satisfação } \\
\text { com avanços alcançados a partir do Plano, em } \\
\text { especial pela aprovação da Lei Maria da Penha e } \\
\text { desafios ainda dependentes de ação. A participação } \\
\text { das mulheres nos espaços de poder e a avaliação da } \\
\text { implementação do Plano foram focos da } \\
\text { Conferência. }\end{array}$ \\
\hline $\begin{array}{l}\text { III Conferência } \\
\text { Nacional de } \\
\text { Políticas para as } \\
\text { Mulheres. Brasília, } \\
12 \text { a 15/12/2011. }\end{array}$ & $\begin{array}{l}\text { III Conferência Nacional } \\
\text { de Políticas para as } \\
\text { Mulheres (SPM, 2013b). } \\
\text { Plano Nacional de } \\
\text { Políticas para as } \\
\text { Mulheres (BRASIL, } \\
\text { 2013). }\end{array}$ & $\begin{array}{l}\text { Mantendo a forma de organização das anteriores, a } \\
\text { III CNPM foi realizada no início do mandato da } \\
\text { primeira Presidenta mulher no Brasil, Dilma Vana } \\
\text { Rousseff, o que foi bastante celebrado na abertura } \\
\text { do evento. Diferente dos planos anteriores, esse, } \\
\text { lém das resoluções das conferências foi elaborado } \\
\text { a partir das proposições de ações dos diversos } \\
\text { órgãos do Governo Federal convocados a participar } \\
\text { do processo propondo ações a serem desenvolvidas } \\
\text { para o segmento. Isso fez com que órgãos como o } \\
\text { Ministério do Esporte se envolvessem pela primeira } \\
\text { vez no Plano e garantiu a ele transversalidade. }\end{array}$ \\
\hline $\begin{array}{l}\text { IV Conferência } \\
\text { Nacional de } \\
\text { Políticas para as } \\
\text { Mulheres. Brasília, } \\
10 \text { a 13/05/2016. }\end{array}$ & $\begin{array}{l}\text { Caderno de Propostas da } \\
\text { IV CNPM (SPM, 2016). } \\
\text { Relatório da IV } \\
\text { Conferência Nacional de } \\
\text { Políticas para as } \\
\text { Mulheres (SOARES; } \\
\text { MELO, 2016) }\end{array}$ & $\begin{array}{l}\text { A Conferência ocorreu em meio ao processo de } \\
\text { impeachment da Presidenta Dilma Rousseff, sendo } \\
\text { este um dos seus últimos atos como governante do } \\
\text { País. O eixo central da CNPM foi discutir a } \\
\text { institucionalidade das políticas para as mulheres. } \\
\text { Com a saída da Presidenta as resoluções aprovadas } \\
\text { pelo processo conferencial não tiveram sequência } \\
\text { como nas anteriores. Os anais do evento não foram } \\
\text { publicados e não houve elaboração de novo PNPM } \\
\text { ou menção de continuidade da implementação do } \\
\text { anterior. }\end{array}$ \\
\hline
\end{tabular}

Fonte: Elaborado pela autora e pelo autor.

\footnotetext{
${ }^{5} \mathrm{O}$ documento foi conseguido pela autora e pelo autor via processo embasado na Lei de Acesso à Informação.
} 
A análise dos itens que vinculam mulheres e lazer no indicou como caminho metodológico a definição das seguintes categorias de análise: 1. do lazer androcêntrico ao lazer de e para todas/os; 2. os tempos das mulheres e o lazer; 3. o direito ao lazer das mulheres e as demandas por políticas públicas; 5. esporte, cultura e outras possibilidades de lazer. Tal categorização foi possível a partir da organização de resoluções, objetivos, ações e falas de palestrantes que constam nos documentos estudados.

\section{Do Lazer Androcêntrico ao Lazer de e para Todas/os}

"Valorizar as iniciativas culturais, de esporte e lazer, respeitando as especificidades e a diversidade das mulheres” (SPM, 2013a, p.91). Essa é a resolução 2.5 da II CNPM. Sua existência nos leva a iniciar com reflexão acerca dos motivos pelos quais tal valorização não existiria.

Carrasco (2012) utiliza o termo androcentrismo para abordar as noções que tratam como universais as referências relativas às experiências dos homens, a exemplo do uso do termo homem como forma de referir-se ao ser humano. Trata-se de uma naturalização das experiências dos "homens" como se universais fossem, tornando invisíveis as das mulheres e de outros grupos que não se "enquadram" no perfil masculino, na elaboração de noções, conceitos, teorias e em situações cotidianas. Isso produz e dissemina conhecimentos enviesados, ao não levar em conta que a humanidade é formada por pessoas com diferenças, semelhanças e desigualdades.

A "naturalização" dessa cultura, focada no masculino, tem consequências em todos os âmbitos da sociedade e o que deveria ser direito de todas/os demanda organização e luta para virar pauta e, quem sabe, realidade. A Resolução 151, da I CNPM, é um exemplo disso: “[...] equipamentos de esporte e lazer voltados para a mulher, integrados à realidade" (SPM, 2004, p.126). 
Por outro lado, a demanda por equipamentos e atividades "voltados para a mulher" pode reproduzir os padrões antrocêntricos criticados, se o entendimento de mulher for o reproduzido por esses padrões. Goellner et al. (2010) alertam para isso, ao analisarem os resultados da divisão entre os grupos que participam das atividades de um programa de esporte e lazer. Apesar de essas atividades permitirem e as diretrizes do programa estimular a participação de meninos e meninas, homens e mulheres, nas mesmas oficinas, a pesquisa identificou uma divisão "naturalizada" de atividade para menino/homem, atividade para menina/mulher e dificuldade de superar essa barreira.

O III PNPM, elaborado de forma mais ampla, com o envolvimento dos órgãos governamentais responsáveis pelas diversas políticas, traz a igualdade e a diversidade como diretrizes do objetivo que trata do acesso ao lazer: "Promover maior participação e assegurar a inserção igualitária das mulheres no esporte e lazer, considerando as dimensões étnicas, raciais, de classe social, orientação sexual, identidade de gênero, geracionais e mulheres com deficiência" (BRASIL, 2013, p.75, grifo nosso). Entre os objetivos específicos, o lazer aparece em três ocasiões:

III. Valorizar e promover a participação das mulheres no esporte e no lazer, favorecendo maior divulgação.

IV. Estimular, ampliar e qualificar o acesso de meninas, adolescentes, mulheres adultas, idosas e mulheres com deficiência ao esporte e ao lazer, promovendo a qualidade de vida, a inclusão social, a cidadania e o desenvolvimento humano (BRASIL, 2013, p.75, grifos meus).

Na sequência há uma meta que prevê o lazer:

E. Desenvolver ações que garantam a implantação de projetos de esporte recreativo e de lazer para a população, com atenção às necessidades das faixas etárias, à acessibilidade, à diversidade cultural, às questões de gênero e às áreas em situação de vulnerabilidade social, atendendo a 553 municípios.

Os objetivos e a meta indicados ocorrem no sentido de superar o olhar androcêntrico que alimenta o perfil patriarcal no tocante ao lazer e ao esporte. Aliados a 
outros marcadores identitários, como raça e classe, o patriarcalismo ${ }^{6}$ e o androcentismo provocam desigualdades, nas quais se incluem aquelas existentes entre mulheres e homens. Além do esporte e lazer, essas desigualdades estão no trabalho, na utilização do espaço e do tempo, nas responsabilidades, nos salários e rendimentos, no reconhecimento, na ocupação de espaços públicos e privados e em outros campos.

Um dos aspectos marcantes, em termos de desigualdade, diz respeito ao trabalho. Tabet (2004) chama a atenção para o fato de que a divisão sexual do trabalho entre os campos público e privado não seja algo natural, tampouco corresponda a uma complementariedade e reciprocidade entre homens e mulheres. Modulada historicamente e socialmente, ela destinou prioritariamente aos homens a esfera produtiva/pública e às mulheres a reprodutiva/privada. Ao mesmo tempo, os homens ocuparam mais funções de valor social agregado (políticas, religiosas, militares etc.), enquanto as mulheres ocuparam atividades consideradas importantes, porém sem valor agregado. Esta divisão entre a esfera produtiva/pública e a reprodutiva/privada alimentou e fortaleceu a hierarquia e a desigualdade entre gêneros distintos.

Romper com essas padronizações é um pré-requisito para a superação de barreiras. Ilustrando a equação, Escaldante (2016) analisou a relação das mulheres com a noite e com o planejamento urbano e afirma que, historicamente, o planejamento tem omitido as contribuições e demandas das mulheres, das pessoas de cor, indígenas, LGBTs e outros grupos, historicamente excluídos das estruturas de poder e tomadoras de decisão. Esta omissão leva a um planejamento focado em interesses simplistas, universalistas e padronizados que não consideram as diversidades presentes nas cidades e replicam as desigualdades, ao privilegiar o modelo "ideal" masculino. As mulheres, em particular,

\footnotetext{
${ }^{6}$ Parry (2015) afirma que, para as feministas, o patriarcado é um sistema social que vincula poder e privilégio, em diversas áreas, aos homens, sem incluir grupos de homens marginalizados, a exemplo dos gays, pobres, de outras raças etc.
} 
têm sido excluídas, em especial do tempo urbano noturno, pelo modo como seus corpos são socialmente definidos e controlados.

Elas são discriminadas em determinados espaços de lazer, seja por questões relacionadas à violência, à inadequação dos espaços, ou mesmo devido às invenções institucionalizadas culturalmente. Exemplificando, Souto Mayor; Isayama (2017), ao analisarem a pesquisa "Lazer no Brasil", em relação às respostas à questão o que faz no fim de semana, chamam a atenção para a diferença percebida na categoria sexo no conteúdo físico-esportivo. Enquanto $64 \%$ dos homens entrevistados indicaram praticar atividades com esse caráter, entre as mulheres, apenas 20,6\% o fizeram.

Souto Mayor; Isayama (2017) relacionam esse tipo de resultado ao histórico da prática esportiva, de atividades físicas e da educação física que chegou a diferenciar as práticas para meninos e meninas, tendendo para a ideia da força masculina e da fragilidade feminina, reforçando estereótipos como os que podem ser visualizados nas lojas de brinquedos para crianças, com o espaço dos meninos repleto de brinquedos de ação e aventura e o das meninas com as tradicionais casinhas, bonecas, maquiagens e enfeites que remetem ao ambiente doméstico e familiar.

Identificadas e reconhecidas as barreiras existentes, abre-se a possibilidade de resistir a elas. Recorremos a Foucault (2010) e suas instâncias de poder e subjetividade para falar do papel das resistências. Para o autor, onde há poder, no caso em questão, identificado no modo androcêntrico e patriarcal de conceber e viver em sociedade, há resistência. Sendo assim, onde estariam e como atuam as resistências a este modelo? A resposta pode estar em atitudes cotidianas de revolta contra o que não é natural e, portanto, não é inevitável e pode ser mudado. Para ilustrar, o III PNPM, ao elencar ações que preveem estímulo e valorização à promoção, ampliação e qualificação da participação das 
mulheres em atividades esportivas e de lazer (BRASIL, 2013), contém um indicativo de reação para superar a barreira que é imposta às mulheres no campo.

Bruhns (2009) indica crescimento dessas resistências, após os movimentos sociais de liberação da década de 1960. Segundo a autora, surgiram manifestações de subjetividade, vinculadas à expressão do desejo, como direito de todos, buscado "não apenas no lazer e nas relações amorosas, mas também no trabalho e em todas as relações sociais" (p.7). É nesse cenário que um novo tipo de participação social aparece, orientado para objetivos, pragmáticos e/ou personalizados, centrados em questões cotidianas, como esportes, feminismo, macrobiótica, sexualismos e outros.

Tomando o lazer como uma dessas questões, Rojek (1995) acredita que a modernidade, da qual esse seria fruto, em sua primeira fase, pode ser encarada como uma grade imposta à vida que disciplinou e ordenou rigidamente o tempo e o espaço, fragmentando-os e atribuindo juízo de valor. Supervalorizou o tempo das ditas atividades “sérias" e desvalorizou as menos "sérias", geralmente relacionadas ao lazer. Apesar disso, o autor acredita ter havido um tempo e um espaço fora do alcance da colonização, os quais mantiveram a individualidade intersubjetiva do prazer e do lúdico, que resistiram ao enclausuramento e difundiram o jogo entre os seres humanos. É nesse espaço de resistência que o lazer se desenvolve(u). Melo (2003, p.55) afirma que

[...] o lazer é uma experiência cultural que não é apenas determinada mecanicamente pela base econômica, nem tampouco é livre e idealizada. É fruto da expressão ativa de relações sociais e das lutas que se estabelecem no cotidiano das camadas populares.

Complementando, Thompson (1998) afirma que o lazer só existe, se pensado nas relações que estabelece com outras dimensões, as quais podem ser concretas, como o trabalho e a educação, ou simbólicas, como as representações que se processam no tempo, acopladas a determinadas formas de se viver em um dado contexto, historicamente convencionadas pelos costumes e ideais disputados e negociados na arena conflitiva de 
interesses denominados culturalmente. No caso das mulheres, o lazer precisa ser pensado considerando tanto as dimensões concretas quanto as abstratas.

A apresentação do capítulo 8 do III PNPM traça o olhar que orienta as ações e envolve valores afetos ao lazer (BRASIL, 2013).

As práticas culturais expressam-se na capacidade que os seres humanos têm de criar símbolos: idiomas, costumes, culinária, modos de vestir, crenças, tecnologias, arquitetura e linguagens artísticas (teatro, música, dança, artes visuais, literatura). Atividades relacionadas às necessidades e bem-estar das pessoas, tanto enquanto indivíduos como sujeitos coletivos (p.74).

Tendo presente que o bem-estar demanda envolvimento de todas as esferas da vida, Bruhns (2009) destaca que os estudos do lazer não podem isolar os comportamentos e práticas de ocupação do tempo livre dos contextos socioculturais nos quais estes acontecem. Assim, tendo presente a amplitude, a diversidade e a heterogeneidade das categorias mulheres e lazer, aproximá-las demanda integrá-las a outras questões que envolvem a vida humana, neste caso, com foco na vida das mulheres. Para auxiliar neste desafio, trago a Resolução 22, da IV CNPM:

Assegurar os direitos das mulheres em todos os seus ciclos de vida, da infância à velhice, nos mais diversos setores: saúde, com ênfase nos direitos sexuais e reprodutivos, garantindo interrupção da gravidez nos casos previstos em lei, educação, transporte, habitação e moradia, emprego, lazer, renda, segurança, saneamento básico e enfrentamento à violência (SOARES; MELO, 2016, p.20, grifo nosso).

Embora a Resolução não deixe explicitada a intencionalidade de integração entre os setores, entendemos que é neste sentido que ele contribuiria para a superação das estruturas dicotômicas, construídas a partir da sexualidade, avançando na construção de paradigmas mais apropriados para a vivência do lazer e a integração das diversas atividades que fazem parte da reprodução social e da sustentabilidade da vida humana. $\mathrm{O}$ prefácio do capítulo "Cultura, esporte, comunicação e mídia", do III PNPM, indica que: 
fortalecer uma imagem feminina sem estereótipos e promover a inserção igualitária de mulheres e homens na área do esporte, seja ele profissional ou não, com especial atenção aos recortes de classe social, étnicas, raciais, geracionais, de orientação sexual e às especificidades das mulheres com deficiência (BRASIL, 2013, p.75, grifo nosso).

As questões alertam para a importância de estudos que desvelem o processo de apropriação do lazer pelas mulheres brasileiras, evitando interpretações empíricas, forjadas pelo modelo androcêntrico de constituição do campo. Dando ênfase a essa necessidade, o III PNPM prevê, no eixo 8, "Promoção do acesso igualitário ao esporte e lazer", ações que propõem o fomento à pesquisa, com fins de realização de diagnósticos e difusão do conhecimento acerca da participação das mulheres em atividades de esporte e lazer e sugere, ainda, a organização de seminários referentes ao tema.

Embora a ação não tenha sido demandada pelas mulheres participantes da III CNPM e sim incluída pelo Ministério do Esporte, sua previsão no Plano se constitui em um estímulo para que o tipo de estudo proposto se amplie e a temática do lazer das mulheres brasileiras passe a ter destaque também no campo acadêmico.

Esses elementos podem contribuir com o processo de emancipação das mulheres, o qual passa pela eliminação da divisão sexual do trabalho, do lazer, do esporte, da cultura e dos demais aspectos da vida das pessoas. Em termos de relações humanas e sociais, não existe neutralidade. "Podemos ir mais além de nossos vários fragmentos: mulheres-homens, privado-político, casa-trabalho, geral-específico e atualizar a utopia de homens e mulheres livres numa sociedade livre" (SOUZA LOBO, 2011, p. 215).

Sem institucionalizarmos esse novo acordo social, será difícil pensar no lazer em que todas e todos estejam inseridas/os com igualdade de oportunidades, tendo respeitadas as suas especificidades, como reivindicado nos documentos das conferências e planos nacionais de políticas para as mulheres.

Um dos aspectos que precisam ser superados no novo acordo diz respeito ao tempo para as diversas atividades que fazem, ou deveriam fazer, parte da vida das pessoas. 


\section{Os Tempos das Mulheres e o Lazer}

O tempo representa um elemento fundamental no bem-estar ou qualidade de vida das pessoas, mas não é homogêneo. Perista (2002) afirma que ele é resultado de uma construção social estabelecida por e, ao mesmo tempo, constitutiva de relações sociais, e expressa um modo de representar e pensar a organização social, por isso, não é neutro, carrega consigo formas de quantificar, qualificar e atribuir valores às atividades humanas.

Entre essas atividades, Perista (2002) considera o trabalho nas duas formas: trabalho remunerado em contexto profissional e trabalho não remunerado no âmbito dos afazeres domésticos. A opção por focar nas duas formas é justificada pelo fato de o trabalho constituir-se como um dos domínios da atividade humana onde a valorização social dos tempos se reflete de modo mais assimétrico. A legislação, as estatísticas e, por vezes, as pesquisas tendem a considerar como trabalho o que é realizado no mercado, enquanto atividade profissional, com remuneração e, nessa concepção, o valor do tempo associado ao "trabalho" representa um bem negociado por dinheiro.

Por essa perspectiva, o chamado tempo livre ou de ócio, avaliado por nós, por Perista (2002), Melo (2003), Souza Lobo (2011) entre outras/os, como um aspecto importante na vida das pessoas, acaba sendo utilizado como variável de ajuste dos outros. Se um deles precisa ser aumentado, ele (o tempo livre) tende a ser diminuído. Isso ocorre por ser tratado como residual, sem valor no mercado. Tal contexto levou as mulheres participantes da III CNPM a reivindicarem, na Resolução 20: "Promover a construção e ampliação de uma rede de equipamentos públicos que aumentem o tempo disponível das mulheres, como as lavanderias comunitárias, restaurantes populares e outras, garantindo a acessibilidade" (SPM, 2013b, p.92). 
A demanda, ao mesmo tempo em que aponta na direção da consciência em relação à falta de tempo livre, procura indicar alternativas em forma de políticas públicas que contribuiriam com a ampliação desse tempo, avançando para além da discussão tradicional da divisão das tarefas domésticas entre homens e mulheres.

As ações sugeridas poderiam contribuir com a liberação de parcela do tempo relacionado às tarefas domésticas, em especial, das mulheres que estão no mercado de trabalho. No caso delas, Carrasco (2012) afirma que é o tempo dedicado a ele que determina o restante do tempo pessoal e social e destaca que, apesar de estarmos falando em flexibilização do tempo de trabalho, é preciso atentar para o fato de que o grau de flexibilidade quase sempre é definido pelo empregador, visando suas necessidades e não as das/os trabalhadoras/es.

Prentou (2016) afirma que parte dos conceitos trata o lazer em relação ao trabalho, ou seja, enquanto tempo livre das obrigações do trabalho remunerado. Apesar disso, acredita que, para as mulheres, o lazer é mais relacionado à possibilidade de ter um tempo para si mesmas. Esta análise considera o fato de que nem todas as pessoas têm períodos de tempo livre determinados, por isso, não se encaixam neste modelo, a exemplo das mulheres, para quem o tempo de lazer é reduzido, pois sempre há algo para ser feito. Acessar o lazer demanda delas a decisão de parar com suas atividades, em determinado momento, e vivenciar o lazer.

Como, então, as mulheres estariam utilizando o chamado tempo livre? Bahia; Brito (2017) identificaram, nos dados da pesquisa Lazer no Brasil, que 58,5\% das pessoas entrevistadas destacaram que seria realizando atividades como afazeres domésticos, ajudando nos deveres, cuidando dos parentes, fazendo compras, lavando o carro, navegando na internet, resolvendo problemas pessoais e realizando trabalhos sociais. Esse pode ser um indicativo de que o tempo livre das pessoas não tem sido utilizado para 
o lazer enquanto um tempo de vivência descompromissada de obrigações ou, "que seu tempo de lazer se torna cada vez mais diminuído e 'estrangulado' diante das demandas de obrigações" (BAHIA; BRITO, 2017, P.100).

Além disso, não há equilíbrio entre homens e mulheres em relação ao tempo livre, como consequência do desequilíbrio nas demais categorias de uso do tempo. Perista (2002) acredita que a diferença entre os padrões de uso do tempo de mulheres e homens está centrada na questão da divisão do trabalho não pago. A autora afirma que parte significativa do trabalho, em especial do trabalho das mulheres, é invisibilizada tanto para a sociedade quanto para as estatísticas e para as políticas públicas. Trata-se do trabalho não pago, associado à reprodução, à execução de tarefas domésticas e à prestação de cuidados, negligenciados enquanto campo do trabalho, ou mesmo das obrigações.

Entre as propostas temáticas da IV CNPM, o lazer apareceu relacionado aos cuidados: “39. Garantir a economia do cuidado com a construção e ampliação de creches, berçários, áreas de lazer, restaurantes populares e esporte em bairros e comunidades" (SOARES; MELO, 2016, p.31, grifo nosso). A proposta sinaliza na direção do cuidado enquanto uma questão que não se restringe à vida privada e às mulheres, ao vinculá-la à ao Estado e à economia.

O cuidado é um aspecto fundamental na vida dos sujeitos: com a vida, com o corpo, com o espírito, com a natureza, com a saúde, com as pessoas da família, com quem sofre e com a casa. No entanto, Carrasco (2012) afirma que:

[...] contudo, o modelo masculino de participação exige liberdade de tempo e de ação para se dedicar ao mercado ou à vida pública, deixando, portanto, pouco espaço para atividades relacionadas com o cuidado das pessoas. Isso significa que, para que esse modelo (masculino) funcione, é necessário que alguém (geralmente, uma mulher) esteja atendendo às necessidades das pessoas que convivem no lar, incluindo aí as necessidades dos homens que estão no mercado ou na vida pública (p.37). 
Para suprir a lacuna deixada pelo modelo masculino e tentar ocupar espaços na vida pública e no mercado de trabalho, Perista (2002) afirma que as mulheres são confrontadas com tempos e temporalidades mais complexos, mais estruturados, mais fragmentados, múltiplos e sobreponíveis.

Um detalhe, percebido entre a III CNPM e o Plano resultante ilustra essa complexidade, isso porque enquanto a Resolução 20 propõe equipamentos públicos com o objetivo de aumentar o tempo disponível das mulheres, sem mencionar o intuito deste aumento, a ação que consta no III PNPM as direciona ao trabalho: "1.3. Ampliação da oferta de equipamentos públicos e de políticas que favoreçam o aumento do tempo disponível das mulheres, promovendo a sua autonomia, inclusive para a sua inserção no mercado de trabalho" (BRASIL, 2013, p.17). Seria esse um indicativo do não reconhecimento do lazer como um direito das mulheres? O foco no trabalho garantiria, no entendimento de quem elaborou o Plano, legitimidade à demanda, corroborando o entendimento de que, em uma sociedade capitalista tem valor aquilo que gera "lucro"?

Perista (2002) reflete acerca da primeira questão que levantamos ao afirmar que, com seus tempos múltiplos e sobreponíveis, as mulheres convivem com a permanente tensão entre o desejo de desempenhar um bom trabalho e desenvolver uma carreira de sucesso e a necessidade de manterem certa distância desses, para garantirem a sobrevivência de outros espaços sociais nos quais elas buscariam realização pessoal.

Corroborando com essa questão, nos painéis realizados na abertura dos trabalhos dos eixos da III CNPM, Tatau Godinho, então Subsecretária de Planejamento e Gestão Interna da SPM, destacou:

Nós não podemos reivindicar a ampliação da participação das mulheres no mercado de trabalho e o nosso direito de trabalhar, de participação política, de autonomia cultural, de lazer, se não garantirmos o investimento em equipamentos sociais que tragam, para a sociedade como um todo, a responsabilidade pelas tarefas domésticas (SPM, 2013b, p.71, grifo nosso). 
Na sequência mencionou: "Se não há condições de cuidado com as crianças em período integral, não se pode cobrar das mulheres que tenham tempo suficiente para a participação política, para o lazer, para o seu desenvolvimento cultural e para o trabalho" (SPM, 2013b, p.71, grifo nosso).

Ainda na III Conferência, Betânia Ávila, representando organizações feministas, reivindicou "Políticas que liberem o tempo das mulheres para produzirem sua autonomia financeira, para avançar nos estudos e na profissionalização, para ter lazer, prazer, e para ter um tempo para si” (SPM, 2013b, p.53, grifo nosso).

Apesar das falas das palestrantes, não foram aprovadas resoluções contemplando o lazer naquele evento, o que pode ser um indicativo da dificuldade enfrentada pelas mulheres participantes daquele evento de colocarem-se enquanto sujeitos desse direito, apesar de a questão do tempo livre perpassar as discussões feministas.

Entre as resoluções da I CNPM identificamos o anseio por tempo livre e a indicação de caminhos vislumbrados pelas participantes para a construção dessa possibilidade, colocando aspectos da vida privada como questões públicas:

46. Estimular o compartilhamento das tarefas domésticas através de uma maior liberação do tempo das trabalhadoras que não incida na remuneração e de campanhas institucionais, construindo e reforçando uma nova cultura referente à divisão sexual do trabalho (SPM, 2004, p.111).

49. [...] redução da jornada de trabalho, sem redução do salário, para aumentar o acesso ao emprego e favorecer também a divisão do trabalho doméstico, propiciando mais tempo livre para as mulheres participarem de outras atividades (SPM, 2004, p. 111 e 112, grifo nosso).

Na II CNPM, além das resoluções, a plenária aprovou recomendações dirigidas a órgãos e organizações. Entre as destinadas ao Estado brasileiro, aparece: "Redução da jornada de trabalho, mantido o mesmo salário, de modo a que homens e mulheres possam também cuidar dos filhos dividindo o trabalho doméstico, cuidar de sua formação, cultura e lazer" (SPM, 2013a, p.103, grifo nosso). 
Como vemos, a busca por tempo recebe destaque na recomendação e nas resoluções das conferências e o trabalho doméstico é lembrado como fator que desequilibra os tempos das mulheres. A pesquisa "Lazer no Brasil" traz dados que permitem examinar aspectos da vida cotidiana e Silva; Moreno e Veraldo (2017) atentaram para os resultados referentes às obrigações espontâneas de homens e mulheres que exerciam trabalho remunerado.

Na faixa etária de 25 a 34 anos, os homens respondentes apontaram $98,90 \%$ de suas obrigações configurando-se como trabalho, seguidos de $28,90 \%$ de famílias e filhos e $27,60 \%$ de afazeres domésticos. Já as mulheres dessa mesma faixa etária responderam $94,30 \%$ para trabalho, percentual seguido de $70,70 \%$ para afazeres domésticos e $52,30 \%$ de famílias e filhos (p.56).

Os autores identificaram, ainda, que no total das entrevistadas, 93,4\% das mulheres que estão no mercado de trabalho o colocaram como principal obrigação, seguido dos afazeres domésticos, obrigatórios para 85,4\% e do cuidado com a família e com os filhos para $57,7 \%$ delas.

Na mesma direção, Perista (2002) analisou os dados do "Inquérito à Ocupação do Tempo 1999”, realizado pelo Instituto Nacional de Estatística de Portugal, e concluiu que, se é possível perceber uma tendência preferencial dos homens pelo trabalho remunerado, a diferença entre o tempo deste tipo de trabalho para homens e mulheres é apenas de cerca de uma hora diária a mais para eles. Por outro lado, quando analisado o trabalho não remunerado (doméstico e de cuidados com a família), as mulheres se dedicam a estes tipos de tarefa três horas a mais que os homens, em cada dia. Além da duração das atividades, a autora chama a atenção para os resultados sobre o total de respondentes, assim, enquanto 94\% das mulheres afirmam realizar trabalho não remunerado apenas $59 \%$ dos homens fazem a mesma afirmação.

Outro dado identificado por Perista (2002) diz respeito a quem se beneficia dos trabalhos não remunerados. "Um exemplo particularmente relevante é o das tarefas 
relacionadas com o cuidado e tratamento da roupa: a esmagadora maioria das mulheres (quase $90 \%$ ) fá-lo para si e para outrem, enquanto quase metade dos homens, quando cuida da roupa, o faz apenas para si próprio" (p.454).

Perista (2002) e Bonalume e Isayama (2018) indicam que os dados de Brasil e Portugal não apontam para mudanças significativas entre as gerações mais jovens, uma vez que os resultados das pesquisas "Inquérito à Ocupação do Tempo 1999” e "Lazer no Brasil” se mantêm ou até mesmo reforçam as diferenças de gênero: “[...] se os rapazes e homens com idades compreendidas entre os 15 e os 24 anos dedicam, em média, apenas 22 minutos, em cada dia, à prestação de cuidados físicos e vigilância de crianças, as raparigas e mulheres do mesmo grupo etário despendem $1 \mathrm{~h} 42 \mathrm{~m}$ neste tipo de tarefas" (PERISTA, 2002, p.462). No caso brasileiro, considerando as/os respondentes com idades entre 11 e 14 anos, 59.67\% das meninas afirmam ter obrigações relacionadas aos afazeres domésticos, contra $35.15 \%$ dos meninos.

Ou seja, se temos assistido, nas últimas décadas, a uma progressiva e rápida aproximação dos padrões de participação de mulheres e homens no mercado de trabalho, o mesmo não se pode dizer, em termos equivalentes, da participação dos homens no trabalho doméstico e na prestação de cuidados à família. Com isso, o tempo para si das mulheres se esvai em atividades para outros.

Garcia (2015) analisa a relação entre pais e filhos no tempo de lazer e constata que a mãe figura como chave no desenvolvimento dos filhos, em termos de lazer e cultura, inclusive por ser a principal responsável pela motivação e organização do que a figura paterna faz com estas crianças no tempo livre. A introdução do eixo "Cultura, esporte, comunicação e mídia”, o III PNPM aponta um entendimento que vai na mesma direção:

[...] com relação ao direito ao lazer, associado ao tempo livre das obrigações sociais, as mulheres também vivenciam limitações significativas, em grande parte resultantes da influência da divisão sexual do trabalho. Para as mulheres, principais responsáveis pelo trabalho usualmente referido como reprodutivo, o lazer é visto como 
relacionado a atividades em família, ao lado das crianças e quase sempre restrito ao espaço doméstico, pouco ou nada se diferenciando da rotina. Aos homens, por outro lado, o lazer é relacionado a atividades destinadas à diversão e em locais públicos (BRASIL, 2013, p.75).

Embora o tempo de lazer represente um elemento fundamental em relação aos diversos aspectos da vida das mulheres, não se trata de algo garantido e homogêneo. É demarcado por vetores como: raça, classe, estado civil, faixa etária, profissão, ser mãe, entre outros. Fica o indicativo de que as questões pessoais interferem diretamente na possibilidade de tempo para as vivências de lazer. A estas se juntam as imposições relacionadas às questões de gênero e barreiras enfrentadas para a vivência do lazer, a exemplo do reconhecimento deste enquanto um direito que demanda políticas públicas.

\section{O Direito das Mulheres ao Lazer e as Demandas por Políticas Públicas}

Falar em direito social ao lazer implica compreender de que lazer vamos tratar e iniciamos por situá-lo como uma dimensão da vida social, cultural e econômica, uma necessidade humana que abarca múltiplas identidades, vivências e formas que variam de acordo com quem as pratica, quando e onde acontecem (GOMES, 2014). Por depender e se relacionar com as outras dimensões da vida social, não é um campo isolado, ou mesmo ausente de tensões e contradições. Em cada ambiente a fruição do lazer altera e é alterada, ensina e constitui diferentes sujeitos, seja pela crítica, pela conformação ou por um misto das duas atitudes (ISAYAMA, 2010).

Como um campo de vivências culturais, marcado pela presença de tensões e ambiguidades, o lazer pode envolver diversão, prazer, trabalho, protesto, cuidados, comemoração, transgressão, convivência, reinvenção, rebeldia, criação, liberdade, autonomia, desigualdade, comodismo e outras variáveis.

O III PNPM traz uma proposta de ação que vai ao encontro desse olhar:

8.7. Estímulo às práticas esportivas pelas mulheres e ampliação de sua participação nos programas e projetos públicos voltados para o esporte 
e o lazer, articulando a incorporação da perspectiva de gênero nas políticas públicas e as dimensões raciais, étnicas, de origem, de classe social, de idade, de orientação sexual, de identidade de gênero e de mulheres com deficiência (BRASIL, 2013, p.80, grifo nosso).

Ao indicar ações que sinalizam para a ampliação na participação em políticas públicas que considerem as especificidades das mulheres, o Plano coloca no poder público uma parcela da responsabilidade pelo lazer delas, considerando-o na categoria dos direitos culturalmente situados. Tal situação implica abordar o entendimento de cultura que, segundo Giroux (2003), é uma dimensão do ser humano, cercada de produção de sentidos e significados, um palco de disputa, no qual diferentes grupos procuram se situar na dinâmica social, com vivências, valores e formas próprias de pensar, estar e agir no mundo. Para Hall (2015), cada ação social tem uma dimensão cultural, uma vez que todas as práticas sociais são expressão de um significado e, como tal, são práticas culturais.

A vinculação da cultura ao lazer, assim como dos dois com os diversos aspectos da vida das pessoas, pode ser ilustrada com uma afirmação da fundamentação do capítulo dez do II PNPM que, ao tratar das necessidades das mulheres jovens, menciona: “[...] oportunidades para utilizar capacidades - acesso ao mercado de trabalho, ao crédito, à renda, aos esportes, ao lazer, à cultura e à terra” (BRASIL, 2008, p.180).

Presente em processos de constituição e negociação o lazer passou a figurar entre os direitos humanos no cenário mundial, na década de 1940, mas foi na Constituição Brasileira de 1988 que conquistou status de direito social. O lazer, a alimentação, o trabalho e os direitos dos trabalhadores rurais e urbanos, a moradia, a segurança, o transporte, a proteção à maternidade e à infância e a assistência aos desamparados passaram a ser considerados direitos sociais, entendidos, de acordo com Coutinho (2000, p. 62), como aqueles que "permitem ao cidadão uma participação mínima na riqueza material e espiritual [e cultural] criada pela coletividade". 
A chegada do lazer a esse patamar, na Constituição Federal de 1988, acompanhado da prescrição de igualdade, sem distinção de qualquer natureza, determinação a qual foi conquistada pelas mulheres, representou avanços e estabeleceu o desafio de superar o marco legal e avançar para a vida real.

Além da Constituição, ou talvez a partir dela, o lazer aparece em marcos legais, como os presentes na Lei de Diretrizes e Bases da Educação Nacional (n. ${ }^{\circ}$ 9.394/96), na Lei Brasileira da Inclusão da Pessoa com Deficiência (n. $\left.{ }^{\circ} 13.146 / 2015\right)$, no Estatuto da Criança e do Adolescente (Lei n. ${ }^{\circ}$ 8.069/90), no Estatuto do Idoso (10.741/2003), entre outros. Na fundamentação teórica, que precede cada plano de ação do II PNPM, são citados trechos da Constituição Federal, do Estatuto da Cidade (Lei 10.257/2001) e da Lei do SUS (n. ${ }^{\circ}$ 8080/90) os quais contemplam o lazer (BRASIL, 2008, p.180). Entendemos tratar-se de um indicativo de avanço no reconhecimento desse direito social. Apesar desse aparato legal, Cristina Buarque, Secretária de Mulheres de Pernambuco, destacou, em sua fala na III CNPM:

Para que a gente tenha uma ideia que nessa briga por direitos nós identificamos as políticas públicas como o espaço para dar a garantia a esses direitos, reconhecendo que $52 \%$ da população brasileira está marginalizada dos processos de decisão. E marginalizada de vários acessos, como o acesso ao conhecimento, acesso ao lazer, acesso ao prazer, acesso à beleza, porque fizeram um verdadeiro escárnio com relação a essa beleza (SPM, 2013b, p.78, grifo nosso).

No caso do lazer, Menicucci (2010) destaca que as políticas públicas da área são iniciativas relativamente recentes e que, apesar de existirem ações que constituiriam uma política nacional de lazer, ainda não se pode assumi-las como algo explícito, articulado ou concretizado, por ser realizado de modo frágil e desarticulado.

O lazer como direito social é um paradoxo, e, por esse motivo, entendo que sua garantia pressupõe um conjunto de superações individuais e coletivas que constroem verdadeiras arenas culturais. Esses espaços de disputa simbólica, em que os conflitos não são cirurgicamente tratados, forjando uma espécie de 'eugenia intelectual' são fundamentais para a 
conquista do lazer como direito social, mas principalmente, para a consolidação e o fortalecimento do processo democrático (SILVA, 2015, p. 161).

Pinto (2014, p. 61) reforça a questão dos tipos de agenda em política pública, afirmando que as ações de desenvolvimento do lazer no Brasil vêm sendo, "sustentadas por políticas diferentes, até mesmo contraditórias, onde cada uma tem o desejo de promover certo tipo de sociedade e determinadas relações entre sujeitos, instituições e setores sociais". Ao ser incorporada pelas pautas transversais, esta diversidade pode mascarar a realidade e colocar foco no caráter funcional do lazer, como uma política destinada a compensar ou reparar problemas sociais de determinados grupos.

Evitar esse tipo de situação demanda entendimentos como o presente na Resolução da I CNPM:

223. Criar e viabilizar políticas públicas descentralizadas que democratizem o direito das mulheres ao lazer e ao esporte, para que tenham condições de manifestar seu potencial criativo e tenham acesso aos bens esportivos culturais produzidos pela humanidade respeitando a terceira idade (SPM, 2004, p.137, grifo nosso).

Com vistas a contribuir para que gestores públicos tenham consciência acerca das opções realizadas ao desenvolver políticas públicas de lazer, Melo (2003) aponta alguns aspectos a serem considerados nos processos de planejamento, desenvolvimento e acompanhamento:

[...] trabalhar os diversos interesses humanos (conteúdos culturais do lazer); construir o equilíbrio entre o consumo e prática das atividades culturais; ampliar o acesso às manifestações da cultura erudita; resgatar as manifestações da cultura popular; criticar as da cultura de massa; e ser uma forma de contribuir para a conscientização dos envolvidos, com a compreensão da dupla dimensão educativa do lazer, sem que isso signifique abandono das características de ludicidade dos momentos de lazer (MELO, 2003, p.126).

Na fala de Tatau Godinho na III CNPM, já mencionada anteriormente, o poder público é lembrado, inclusive em relação ao lazer. "É preciso cobrar também em cada esfera de governo para que haja o investimento efetivo na infraestrutura social necessária 
para que as mulheres possam ter igualdade no mundo político, no mundo do trabalho, no mundo do lazer e no mundo da cultura" (SPM, 2013b, p.72, grifo nosso). A afirmação chama a atenção à amplitude do conceito de lazer que o coloca enquanto possibilidade de ação intersetorial, em políticas públicas diversas.

Acreditamos ser coerente pensar no lazer presente, talvez de forma indireta, em áreas como: Educação, Saúde, Desenvolvimento Social, Previdência, Meio Ambiente, Desenvolvimento Econômico, Trabalho e Emprego, Direitos Humanos e outras. Mais diretamente, as demandas por lazer se vinculam às pastas responsáveis pelo próprio tema, quando existentes, pelo Esporte, pelo Turismo e pela Cultura, e cada um destes campos representa uma possibilidade contribuição com as políticas de lazer.

A análise dos materiais referentes aos PNPM, nos quais constam responsáveis pelas ações elencadas, mostra demandas por lazer vinculadas a áreas diversas, como Educação, Cultura, Segurança Pública e Esporte. Isso aparece com mais ênfase nos dois primeiros, quando o Ministério do Esporte não esteve envolvido na elaboração. No momento em que isso ocorreu, no III PNPM, as demandas passaram ter um direcionamento a ele e a programas e ações de sua responsabilidade, a exemplo da Meta $\mathrm{D}$, que é "Incluir a equidade de gênero nas diretrizes de todos os projetos de esporte, lazer e atividade física implementados pelo Ministério do Esporte" (BRASIL, 2013, p.76, grifo nosso). As ações propostas para alcançá-las seguiram na mesma direção.

8.7.1. Estimular a criação do Comitê de Gênero no Ministério do Esporte e a adoção de políticas para inserção igualitária das mulheres no esporte e lazer nos estados, Distrito Federal e municípios.

8.7.2. Estimular a participação de meninas e adolescentes nas atividades esportivas nas escolas, nos Programas Segundo Tempo, Esporte e Lazer da Cidade, Recreio nas Férias, bem como nas Olimpíadas Escolares e Universitárias.

8.7.3. Estimular a participação das mulheres adultas e idosas nos Programas Vida Saudável, Esporte e Lazer da Cidade e Pintando a Cidadania (BRASIL, 2013, p.80, grifo nosso). 
Embora essas menções específicas por lazer, vinculadas ao esporte, tenham aparecido apenas em 2013, no III PNPM, a reivindicação por espaços e equipamentos é anterior e mais frequente nos planos e nas CNPM.

151. Garantir políticas que organizem os espaços públicos, refletindo a possibilidade de convívio com as diferenças de gênero, raça e etnia, geração, classe social, orientação sexual e deficiência, garantindo equipamentos e serviços adequados às suas necessidades tais como creches, postos de saúde, espaços de esporte e lazer, saneamento, etc, equipamentos de esporte e lazer voltados para a mulher, integrado à realidade (SPM, 2004, p.126, grifos nossos).

A resolução da I CNPM aponta para a necessidade de um planejamento integrado do espaço público. A urbanização, o crescimento do número de habitantes, o avanço tecnológico do mundo do trabalho e do modelo de organização espacial das cidades separam física e simbolicamente as pessoas. Além do distanciamento físico, isso dificulta a sociabilidade, reforça a fragmentação das identidades coletivas e sociais, favorecendo o individualismo, com possibilidade de vir a ser um elemento que contribui para a inferiorização de determinados segmentos sociais transformando a segregação, o isolamento e a discriminação em hábito.

Pela primeira vez na história, mais da metade da população está vivendo em áreas urbanas (estima-se 60\% em 2030): serão 24 megalópoles com mais de 10 milhões de habitantes. Godbey (2011) ressalta que isso ampliará as diferenças de comportamento, inclusive no lazer, antes marcadas por questões como classe social, renda e etnia, para o campo das diferenças culturais dos residentes urbanos e visitantes. Na direção das necessidades provocadas por esse processo, a Plataforma Política Feminista (AMB, 2002) menciona, no desafio 113 :

Aumentar o investimento de recursos em projetos habitacionais que garantam direito à moradia e a terra urbana, assegurados a infraestrutura necessária, o transporte, e os demais serviços públicos, bem como os equipamentos sociais de apoio às tarefas domésticas, e ainda os espaços de lazer para as gerações presentes e futuras" (AMB, 2002, p.16, grifo nosso). 
O desafio foi aprovado novamente, com texto praticamente idêntico, na I CNPM, sem a adjetivação "para as gerações presentes e futuras”. Essa Conferência aprovou, ainda, a resolução 153 que prevê: "Implantar serviços e equipamentos como lavanderias e restaurantes públicos, centros de convivência (esporte, cultura e lazer)” (p.127, grifo nosso). No III PNPM, também constam ações que reiteram a necessidade de investimentos e disponibilização de equipamentos esportivos e culturais para o lazer.

Para se evitar que o processo de urbanização torne a vida humana nas grandes cidades algo penoso e arriscado, é preciso que se pense o planejamento urbano resgatando a funcionalidade e a qualidade dos logradouros públicos para toda a população, como sugere a resolução da I CNPM. Lefebvre (1999) afirma que uma cidade ambientalmente equilibrada tem como objetivo o planejamento integrado e o uso do espaço urbano e rural com visão de futuro, contemplando as atividades humanas e os elementos naturais de reprodução da vida em sociedade e não a mera reprodução do capital.

Nessa direção, a I CNPM contou com um eixo que vinculava bem-estar e qualidade de vida das mulheres à saúde, moradia, infraestrutura, equipamentos sociais e recursos naturais. As resoluções trazem demandas por espaços de lazer como esta: 148. “[...] equipamentos sociais de apoio ao trabalho doméstico e espaços de qualificação profissional, cultura e lazer para famílias com renda de zero a cinco salários mínimos” (SPM, 2004, p.126, grifo nosso).

A demanda, embora não visando à universalidade, corrobora com a ideia de que pensar o lazer implica, necessariamente, pensar o espaço urbano, levando em consideração a sua dimensão coletiva. Lefebvre (1999) afirma isso, ao tratar da importância do tempo, dos ritmos da cidade e do habitante, e defender o direito do morador urbano à cidadania, ou seja, a um espaço que lhe garanta o direito à educação, 
ao trabalho, à cultura, ao descanso, à saúde e à moradia. Essa dimensão coletiva do espaço urbano precisa estar presente nos processos de planejamento.

Barbosa; Liechty e Pedercini (2013) reforçam a constatação já abordada de que parte dos espaços públicos, em especial de lazer, foi pensada a partir da figura masculina, prestando pouca atenção nas diferentes realidades vividas pelos habitantes de uma cidade, a exemplo das mulheres. Grandes parques distantes de onde as pessoas moram, pouca segurança e até falta de banheiros afastam mais as mulheres do que os homens.

Há resoluções como a da IV CNPM que vão além da reivindicação por espaços e equipamentos e chamam a atenção para as necessidades de políticas que atendam as demandas das mulheres como "criar espaços culturais e programas de lazer para as mulheres" (SOARES; MELO, 2016, p.33, grifo nosso).

Por isso, ao se discutir as práticas e experiências nos espaços urbanos, um aspecto é relevante: o uso desses espaços como lugares de lazer. Nesse âmbito, há de se considerar a crescente presença desse elemento nas pautas de discussão dos pesquisadores, dos políticos e da sociedade em geral, uma vez que, sendo um direito social, o lazer pode ser vivenciado de diferentes formas e em lugares diversificados.

\section{Esporte, Cultura e Outras Possibilidades de Lazer para as Mulheres}

A festa, a dança, o jogo, a brincadeira, o esporte; assistir a um filme, a um programa televisivo, a um jogo ou a um espetáculo; ir ao teatro; ouvir música; fazer pintura, desenho, escultura, artesanato; ler; passear; navegar na internet; viajar; vivenciar práticas corporais e diversas outras possibilidades representam manifestações culturais que constituem o lazer. Gomes; Ramos e Serejo (2010) afirma tratar-se de práticas sociais vivenciadas de maneiras diversas e com significados singulares para as pessoas que as usufruem ludicamente, em tempos e espaços sociais determinados. Essas manifestações, 
histórica, social e culturalmente situadas, representam práticas que integram a cultura de cada povo, assumindo múltiplos significados, a depender do tempo/espaço social/contexto em que se inserem e do papel que representam para os sujeitos, para os grupos sociais, para as instituições e para as sociedades que as vivenciam.

As demandas por lazer, identificadas nos documentos das conferências e planos nacionais de políticas para as mulheres, o relacionam a áreas diversas e indicam formas de vivência que contemplam possibilidades variadas. Para exemplificar, a ação 4.1.14. do II PNPM, previu: "Promover atividades culturais (teatro, música, cineclube, dança, leitura e literatura, artes visuais) para as mulheres em situação de violência, por meio da atuação dos agentes culturais diretamente na Rede junto às comunidades e nos Pontos de Cultura (BRASIL, 2008, p.106). No I PNPM, constava: “Apoiar projetos voltados para as práticas esportivas e culturais das diversas matrizes no ambiente escolar" (BRASIL, 2004, p.58).

Apesar de atentarem para a possibilidade de vivências diversificadas, as resoluções não contemplam as mulheres em geral restringindo o acesso àquelas que estão em situação de violência. No tocante à menção ao ambiente escolar, a ação não especifica as mulheres, permitindo a interpretação de que esse não seja o recorte sugerido. Os motivos disso remetem ao não reconhecimento do lazer como direito universal.

Ainda em relação a essas duas ações, percebe-se a vinculação entre lazer e atividades culturais. Leiva e Meirelles (2018) apresentam o estudo "Cultura nas Capitais", realizado a partir da pesquisa aplicada em doze capitais brasileiras acerca do consumo cultural do público, partindo do pressuposto de que a cultura envolve um espectro amplo que vai "de pequenos hábitos cotidianos a crenças religiosas, passando por práticas de lazer, moda e gastronomia" (p.25).

Os resultados se aproximam do que afirma Gomes; Ramos e Serejo (2010) e dos resultados da pesquisa apresentada por Stoppa; Isayama (2017), ao identificarem que o 
nível de escolaridade, a classe social, a faixa etária e o gênero são determinantes da quantidade e qualidade do acesso aos espaços e eventos culturais, assim como às atividades de lazer. O destaque geral é para a escolaridade, apesar de a renda também representar um fator facilitador/inibidor, a baixa escolaridade afasta as pessoas das atividades culturais e limita a diversificação entre as opções de lazer.

As mulheres demonstram mais interesse pelas atividades culturais que os homens, no entanto, acessam menos estas mesmas atividades, com uma exceção vinculada à escolaridade: “depois de cerca de doze anos de estudo (equivalentes ao ensino médio completo), a relação se inverte: elas vão a uma diversidade maior de eventos culturais" (LEIVA; MEIRELLES, 2018, p.69).

O II e o III PNPM refletem esse interesse indicando ações como:

6.1.7. Apoiar a implantação de Pontos de Cultura nas Unidades de Conservação de Uso Sustentado voltados para o saber feminino (BRASIL, 2013, p.136).

8.1.4. Implantar Pontos de Cultura especificamente voltados para a questão de gênero, considerando as especificidades étnico-raciais, de geração e de orientação sexual (p.163).

8.1.5. Ampliar a perspectiva e a temática de gênero nos Pontos de Cultura existentes (p.163).

8.1.6. Capacitar os pontos de cultura mulher como produtores de conteúdo para a TV Pública (p.163).

8.1.7. Ampliar o número de Pontos de Cultura Mulher (p.163).

Nessas ações a relação entre as mulheres e a cultura, enquanto uma possibilidade de lazer, é enfatizada e não se restringe a grupos específicos, como em ações analisadas anteriormente. Reconhecer a existência de especificidades e considerá-las nas ações reivindicadas e implementadas, sem, com isso, reforçar estereótipos que excluem as mulheres de determinadas vivências é importante na construção do lazer como direito.

Outro conteúdo cultural de lazer, presente no material analisado, relaciona mulheres e esportes e/ou atividades físicas. A resolução 208 da I CNPM demanda 
[...] considerar as práticas esportivas como ações educativas fundamentais, formativas e de saúde, que deverão contemplar ações conjuntas com os profissionais de educação física, com o objetivo de desenvolver metodologias de atividades físicas atentando para a dimensão de gênero, referenciando conteúdos e práticas na área da educação física e esportiva e de lazer (SPM, 2004, p.135, grifo meu).

Em relação a esse aspecto, tanto a pesquisa "Cultura nas Capitais" quanto a "Lazer no Brasil" apontam que as mulheres praticam menos atividades físicas do que os homens e ficam mais em casa. No III PNPM (BRASIL, 2013) aparece a referência ao direito das mulheres à prática esportiva, lembrando que, no Brasil, até o ano de 1979, elas eram proibidas de praticar lutas e jogar futebol, esportes considerados incompatíveis com o que se via como adequado às mulheres.

Goellner et al. (2010) realizaram uma pesquisa para perceber as motivações que envolvem a participação das pessoas nas atividades desenvolvidas no programa de esporte e lazer investigado. As conclusões indicam haver diferenças significativas entre as formas e as motivações que levam à participação de homens e mulheres em atividades. Questionados na pesquisa a respeito do que gostam de fazer no tempo livre e o que entendem por lazer, homens e mulheres deram respostas diferenciadas, ficando os homens no viés voltado para o espaço público, com esporte, convivência com amigos, festas e afins e as mulheres no âmbito doméstico, com descanso, atividade física, atividades familiares, assistir à televisão e até pequenas atividades domésticas. Ou seja, enquanto a mulher foca no descanso, na saúde, na casa e na família, o homem pensa no lazer como diversão, liberdade, relaxamento. Acerca disso os autores afirmam que

[...] no curso da história, homens e mulheres foram educados praticando exercícios diferentes, o que era aconselhado para os homens não correspondia ao que as mulheres deveriam realizar. Essa separação, baseada na biologia dos corpos, terminou por engendrar-se na cultura brasileira determinando o que é masculino e o que é feminino [...] (p.1316) 
Como consequência, na pesquisa Lazer no Brasil o esporte aparece na terceira ou mesmo quarta indicação no que as mulheres fazem no tempo livre, subindo para segundo lugar, em alguns casos, quando a questão é o que se gostaria de fazer. Enquanto $31 \%$ dos homens participantes afirmam praticar atividades físico-esportivas nos fins de semana, 10\% das mulheres o fazem (BONALUME e ISAYAMA, 2018).

Na mesma direção, enquanto os resultados da pesquisa "Cultura nas Capitais" apontam que mulheres assistem mais à televisão e leem livros, entre os homens, o esporte se sobressai. Leiva e Meirelles (2018) concluem que isso resulta no maior uso das mídias eletrônicas, leitura de livros não didáticos e tarefas domésticas pelas mulheres. As duas primeiras atividades podem ser consideradas lazer, enquanto as tarefas domésticas que são maioria, se referem a obrigações familiares. Enquanto os dados demonstram que casamento não muda esse cenário, a existência de filhos menores de 12 anos aumenta mais a distância entre o interesse e a realidade para as mulheres, em relação aos homens. Quanto menor a renda, maior a desvantagem para as mulheres. "Virar mãe reduz mais o acesso a atividades culturais que se tornar pai” (LEIVA e MEIRELLES, 2018, p.57).

Ter filhos na faixa etária mencionada aumenta a chance de os homens irem a atividades fora de casa (como cinema, museus, concertos e festas populares), enquanto que, com as mulheres, acontece o contrário. Embora participem das atividades dos filhos elas reduzem as que faziam anteriormente. "Os homens parecem continuar fazendo o que faziam e ainda incorporam algumas das atividades culturais para levar os filhos, ao passo que às mulheres cabe cuidar das crianças em casa" (LEIVA e MEIRELLES, 2018, p.69).

Como vimos, os dados analisados indicam que as pessoas enfrentam barreiras diversas nas variadas formas de vivência do lazer. Os processos são submetidos a relações de poder e estas atuam nos comportamentos corrigindo condutas culturalmente consideradas inadequadas, ou seja, certos padrões de comportamento histórica e 
culturalmente instituídos podem ser modificados. A restrição imposta às mulheres para viverem determinadas práticas, desenvolverem certas habilidades e competirem em alguns jogos interessa à manutenção das diferenças de gênero, por isso, é descrita como natural e tende a ser mantida, se não houver resistência.

Diante das diversas restrições encontradas pelas mulheres para vivenciarem o lazer, identifiquei e apontei como ele foi abordado nas conferências e planos nacionais. Será possível inferir, a partir dos documentos, que há um movimento crescente de resistência a essas barreiras?

\section{O Lazer nas Conferências e nos Planos Nacionais de Políticas para as Mulheres: Um}

\section{Balanço}

Tendo analisado os documentos de cinco conferências e os três planos nacionais de políticas para as mulheres, considerando a citação explícita da categoria lazer ${ }^{7}$, encontramos o seguinte cenário:

\section{Gráfico 02: O lazer nas conferências e planos nacionais de políticas para as mulheres.}

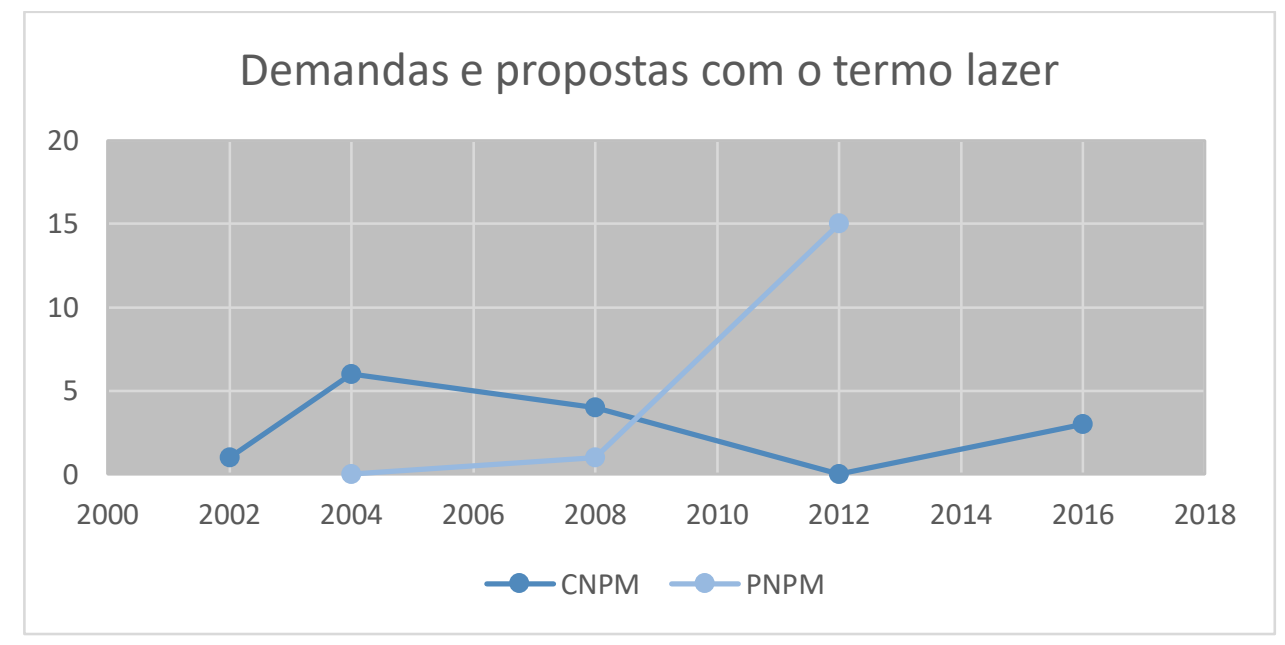

Fonte: Elaborado pela autora e pelo autor

7 Consideramos a presença da palavra lazer em resoluções, moções e recomendações, no caso das conferências, e em linhas de ação, objetivos gerais e específicos, ações e metas, nos planos. Excluímos as menções que aparecem nas falas (palestras) e nos textos introdutórios dos eixos dos planos, considerando que não representam uma pactuação das participantes. 
O Gráfico demonstra que não há continuidade e linearidade nas demandas por lazer nas conferências. No tocante aos três planos elaborados (as conferências de 2002 e 2016 não geraram planos), percebe-se um crescimento significativo entre os dois primeiros e o terceiro cujo contexto foi diferenciado pela forma de condução da elaboração.

O ano de 2002 representa a Conferência Nacional de Mulheres de 2002 (AMB, 2002) e o lazer é indicado explicitamente como uma das demandas do setor em dois dos 269 desafios elencados, além de uma possível sugestão relacionada a ele, ao tratar da questão do bem-estar.

Em 2004 foi realizada a que é considerada a I CNPM, convocada pelo governo federal e o documento da SPM (2004) destacava, na programação, entre as atividades, apresentações artísticas e shows das cantoras Margarete Menezes e Elba Ramalho. Entendemos que isso representava a inclusão de momentos de lazer para as participantes da Conferência. Em relação aos resultados, das 239 resoluções, o lazer foi citado diretamente em seis, havia, ainda, duas resoluções que abordavam a necessidade de tempo livre, sem menção da utilização desse tempo, por isso, não as consideramos no grupo.

Um diferencial das resoluções da I CNPM, em relação as demais, é que três delas traziam demandas diretas por lazer, vinculando-o ao esporte, às atividades físicas e culturais, sem que isso fosse feito em um rol geral de demandas, como tendeu a ocorrer na maior parte dos casos. Apesar disso, o PNPM, resultante da Conferência, não trazia nenhuma menção ao lazer.

Em 2008, na II CNPM, havia cerca de 233 resoluções e recomendações aprovadas $^{8}$ e a análise indicou demanda por lazer em três momentos. Um destes tratava especificamente de lazer, esporte e cultura, voltados às mulheres, o outro o elencava no

\footnotetext{
${ }^{8} \mathrm{Nem}$ todas as resoluções, recomendações e propostas foram numeradas e não consta no documento justificativa para tal atitude.
} 
rol de demandas e o lazer era citado em uma moção aprovada que tratava de segurança pública. O II PNPM (BRASIL, 2008) citava uma ação que previa lazer, restrito ao sistema prisional feminino. Sem mencionar o termo lazer, apareciam ações relacionadas ao acesso a atividades culturais, em especial, via Pontos de Cultura.

A III CNPM, em 2012, aprovou 91 resoluções e nenhuma mencionava o lazer, apesar de ele ter sido citado nas falas de abertura (palestras) de alguns eixos. O esporte, o turismo e as atividades físicas e culturais também não foram mencionados, entretanto, no III PNPM o lazer foi citado quinze vezes, considerando linhas de ação, objetivos gerais e específicos, ações e metas. Além dele, estavam contemplados a cultura, o esporte e, pela primeira vez, o turismo. Saliento que esse plano foi elaborado a partir da III CNPM, mas, principalmente, de uma ação transversal no governo federal, na qual cada órgão teve a responsabilidade de apresentar propostas.

A última conferência da série histórica, até o momento, foi a IV CNPM, realizada em 2016, e no relatório constavam 94 resoluções ou propostas temáticas que mencionavam o lazer duas vezes, em um rol que apresentava diversas demandas.

Além dos dados encontrados, o lazer pode estar incluído em demandas lançadas de forma genérica, a exemplo desta que consta da I CNPM: “70. Estender à empregada doméstica todos os direitos assegurados às demais trabalhadoras e trabalhadores inseridos no mercado formal de trabalho. (SPM, 2004, p.114, grifo nosso). No entanto, considerando a dificuldade de associação, uma vez que o lazer poderia, ou não, ter sido lembrado como um dos referidos direitos, optamos por não considerar esse tipo de alusão. 


\section{Considerações Provisórias}

Sem a pretensão de tecer conclusões absolutas, os achados da pesquisa conduzem a algumas reflexões: 1 . a temática do lazer, embora sem muita representatividade, se faz presente nas demandas elencadas nas CNPM e nos PNPM; 2. o mais comum é lembrar do lazer quando estão sendo relacionadas demandas diversas e não trazê-lo como reivindicação específica; 3 . vivenciar lazer durante os trabalhos das conferências e/ou ouvir sobre ele em palestras que antecedem às discussões não parece ter feito com que fosse mais ou menos incluído nas resoluções; 4. aprovar ou não resoluções que contemplam o lazer nas conferências não representou garantia de inclusão ou exclusão nos respectivos PNPM; 5. o envolvimento dos órgãos gestores responsáveis pelas políticas específicas como o lazer e a cultura favorece a inclusão das pautas nos PNPM; 6. o fato de o lazer ter sido priorizado em uma CNPM ou no atinente PNPM não significa que na/no seguinte isso se repita ou haja maior ênfase; 7. em boa parte das menções ao lazer nos documentos, ele é tratado como viés de vivência significativa, humanizada, integrada e contextualizada, sem caráter compensatório e/ou utilitarista; 8. não foi possível estabelecer relação entre o momento político e as demandas por lazer, uma vez que não houve variação significativa, a exceção do III PNPM cuja justificativa diz respeito a um aspecto que parece ser de gestão.

As indicações iniciais nos levam a pensar que, apesar da amplitude e do potencial para contribuir com vivências que oportunizem prazer, aprendizagens, socialização, bemestar, saúde e outros ganhos, sem desconsiderar que há aspectos negativos a ele vinculados, o lazer ainda tende a ficar relegado a segundo plano. Neste sistema, a obrigação é vista como necessidade moral, dever, encargo e precisa estar em primeiro lugar na agenda das pessoas. 
A invisibilidade ideológica na relação mulheres e lazer parece persistir, mesmo que, em alguns momentos, percebam-se esboços de incluí-la no foco das atenções.

\section{REFERÊNCIAS}

ABERS, Rebecca, SERAFIM, Lizandra, TABAGIRA, Luciana. Repertórios de Interação Estado-Sociedade em um Estado Heterogêneo: A Experiência na Era Lula. Dados [online]. 2014, v.57, n.2, p.325-357.

AMB (Articulação de Mulheres Brasileiras). Plataforma Política Feminista. Recife, PE, 2002. Disponível em: https://www.institutobuzios.org.br/documentos/PLATAFORMA\%20POLITICA\%20FE MINISTA.pdf. Acesso em 13 nov. 2018.

AMB. A revista Memória II ENAMB - Transformando o mundo pelo feminismo. II Encontro Nacional da AMB. 2011. Disponível em: https://www.articulacaodemulheres.org.br/.Acesso em 13 dez. 2018.

AVRITZER, Leonardo. Conferências Nacionais: ampliando e redefinindo os padrões de participação social no Brasil. RJ, IPEA, texto para discussão 1.739, 2012. Disponível em: https://www.ipea.gov.br/participacao/images/pdfs/td 1739.pdf. Acesso: 22 jan. 2019.

BAHIA, Mirleide. C.; BRITO, Ronivaldo dos S. B. O lazer do Brasileiro: como é vivenciado o tempo; In: STOPPA, Edmur A. e ISAYAMA, Helder F. (org.). Lazer no Brasil: representações e concretizações das vivências cotidianas. Campinas, São Paulo: Autores Associados, 2017.

BARBOSA, Carla; LIECHTY, Toni.; PEDERCINI, Raquel. Restrições ao lazer feminino: particularidades das experiências de lazer de mulheres Homossexuais. Revista Licere, Belo Horizonte, v.16, n 2, junho/2013.

BONALUME, Claudia. R.; ISAYAMA, Helder. F. As Mulheres na Pesquisa O Lazer do Brasileiro. Revista Brasileira de Estudos do Lazer, v. V, p. 3-24, 2018.

BRASIL. Plano Nacional de Políticas para as Mulheres. - Brasília: Secretaria Especial de Políticas para as Mulheres, 2004. Disponível em: https://www.spm.gov.br/assuntos/pnpm/plano-nacional-politicas-mulheres.pdf. Acesso em: 06 jan. 2019.

. II Plano Nacional de Políticas para as Mulheres. Brasília: Secretaria Especial de Políticas para as Mulheres, 2008. Disponível em: https://portal.mec.gov.br/dmdocuments/planonacional_politicamulheres.pdf. Acesso em: 06 jan. 2019.

. Plano Nacional de Políticas para as Mulheres. Brasília: Secretaria Nacional de Políticas para as Mulheres, 2013. Disponível em: https://www.spm.gov.br/assuntos/pnpm/publicacoes/pnpm-2013-2015-em-22ago13.pdf. Acesso em: 28 jan. 2019. 
BRUHNS, Heloísa T. A crise do Lazer Moderno e concepções de corpo. Revista Licere, Belo Horizonte, v.12, n 4, Dez./2009.

CARRASCO, Cristina. Estatísticas sob suspeita: proposta de novos indicadores com base na experiência das mulheres. SOF: Sempreviva Organização Feminista, São Paulo, 2012.

COUTINHO, Carlos Nelson. Notas sobre cidadania e modernidade. Disponível em: www.assistentesocial.com.br/agora3/coutinho.doc. Acesso em: 22 jun. 2016.

ESCALDANTE, Sara O. Where is women's right to the night in the new urban agenda? The need to include an intersectional gender perspective in planning the night. Towards Habitat III: a gender perspective. Special Issue, Università degli Studi Federico II di Napoli. v.9, n.1, p.165, june 2016.

FOUCAULT, Michel. Polêmica, Política e Problematizações. In: FOUCAULT, M. Ditos e escritos V: Ética, sexualidade, política. 2. ed. Rio de Janeiro: Forense Universitária, 2010 .

GARCIA, Carla C. Breve história do feminismo. 3. ed. São Paulo: Editora Claridade, 2015.

GIROUX, Henry A. Atos Impuros: a prática política dos estudos culturais. Porto Alegre: Artmed, 2003.

GODBEY, Geoffrey. The customization of life and leisure: as mediator in the manufacture of value of joy in the context of communication policy. Revista Hospitalidade, v. 8, n. 1, junho de 2011.

GOELLNER, Silvana; et al. Lazer e Gênero nos Programas de Esporte e Lazer das Cidades. Revista Licere, Belo Horizonte, v.13, n 5, Dez./2010.

GOMES, Christiane L.; RAMOS Alícia M. O.; SEREJO, Hilton F. B. Conhecimentos sobre o Lazer nos Cursos de Graduação em Turismo de Minas Gerais. In Turismo em análise, v. 21, n. 2, agosto de 2010, p.357 a 380 .

Lazer: necessidade humana e dimensão da cultura. Revista Brasileira de Estudos do Lazer. Belo Horizonte, v. 1, n.1, p. 3-20, jan/abr. 2014.

HALL, Stuart. A identidade cultural da pós-modernidade. Tradução: Tomaz Tadeu da Silva e Guacira Lopes Louro, 12. Ed. Lamparina, 2015.

ISAYAMA, Helder Ferreira. Formação Profissional no âmbito do lazer: desafios e perspectivas. In: ISAYAMA, Helder (Org.). Lazer em Estudo: currículo e formação profissional. Campinas: Papirus, 2010. p. 9-25.

LEFEBVRE, Henri. A revolução urbana. Belo Horizonte, Editora UFMG, 1999.

LEIVA, João e MEIRELLES, Ricardo (org). Cultura nas capitais: como 33 milhões de brasileiros consomem diversão e arte. Rio de Janeiro: 17Street Produção Editorial, 2018.

MELO, Victor Andrade. Lazer e minorias sociais. São Paulo: IBRASA, 2003. 
MENICUCCI, Telma M. G. e BRASIL, Flávia de P. D. Construção de agendas e inovações institucionais: análise comparativa da reforma sanitária e da reforma urbana. Textos para discussão. Escola de Governo/FJP. Estud. sociol., Araraquara, v.15, n.29, p.369-396, 2010.

PARRY, Diana C. The relational politics of gender and leisure. In: WALKER, Gordon J., SCOTT, David and STODOLSKA, Monika (org.). Leisure matters: the state and future of leisure studies. Venture Publishing, Inc., State College, Pennsylvania, 2015.

PEDRO, Joana M. Lugar de mulher é onde ela quiser. Sem limites. Entrevista a Marina Lemle. Blog de História, Ciências, Saúde - Manguinhos, RJ, 2018. Disponível em: https://www.revistahcsm.coc.fiocruz.br/joana-maria-pedro-lugar-de-mulher-e-onde-elaquiser-sem-limites/. Acesso em: 10 maio 2018.

PERISTA, Heloísa. Gênero e trabalho não pago: o tempo das mulheres e o tempo dos homens. Análise Social, v. 36, n. 163, p. 447-474, 2002.

PINTO, L. M. S. de M. Seminário Nacional de Políticas Públicas de Esporte e Lazer Construindo políticas públicas de lazer no Brasil. In: TONDIN, G.; VIDAL, J. R.; FEIX. E. (Orgs). SEMINÁRIO NACIONAL DE POLÍTICAS PÚBLICAS DE ESPORTE E LAZER, 11. Canoas. Anais... Porto Alegre: CORAG, 2014.

PRENTOU, Polina. The gendered of leisure young women in Athens. Towards Habitat III a gender perspective. Special Issue, Università degli Studi Federico II di Napoli. v.9, n.1, p.67, june 2016 .

ROJEK, Chris. Decentring Leisure: Rethink Leisure Theory. Sage, London: Thousand Oaks, 1995.

SILVA, Débora A. M. O lazer como campo: desafios à concretização do direito social em um Brasil "em construção" democrática. In: GOMES, Christianne Luce; ISAYAMA, Hélder Ferreira. Direito social ao lazer no Brasil. Campinas: Autores Associados, 2015. p.157-182.

SILVA, Luciene. F. da; MORENO, José C. de A.; VERALDO, Katyucia. C. Relações com o trabalho. In: STOPPA, Edmur A.; ISAYAMA, Helder F. (org.). Lazer no Brasil: representações e concretizações das vivências cotidianas. Campinas: Autores Associados, 2017.

SOARES, Vera Lúcia L.; MELO, Jacira Vieira de. Relatório da IV Conferência Nacional de Políticas para as Mulheres. ONU Mulheres, Brasília: SPM, 2016, Mineo.

SOUTO MAYOR, Sarah; ISAYAMA, Hélder F. O lazer do brasileiro: sexo, estado civil e escolaridade. In: STOPPA, Edmur A.; ISAYAMA, Helder F. (org.). Lazer no Brasil: representações e concretizações das vivências cotidianas. Campinas: Autores Associados, 2017.

SOUZA-LOBO, Elizabeth. A classe operária tem dois sexos: trabalho, dominação e resistência. São Paulo: Fundação Perseu Abramo/Secretaria Municipal de Cultura/Brasiliense, 2011. 
SPM. Conferência Nacional de Políticas para as Mulheres: Anais. Brasília, Presidência da República, Secretaria Especial de Políticas para as Mulheres. SPM, 2004. Disponível em: https://www.spm.gov.br/assuntos/pnpm/anais.pdf/view. Acesso em: 06 jan. 2019.

SPM. Conferência Nacional de Políticas para as Mulheres, 2. Anais... Brasília, DF, 2013a. Disponível em: https:/www.spm.gov.br/assuntos/pnpm/publicacoes/anais-da-2aconferencia. Acesso em: 09 jan. 2019.

SPM. Conferência Nacional de Políticas para as Mulheres: autonomia e igualdade para as mulheres, 3. Anais... Brasília, DF, 2013b. Disponível em: https://www.spm.gov.br/assuntos/pnpm/publicacoes/anais-da-3a-conferencia. Acesso em: 12 jan. 2019.

SPM. Conferência Nacional dos Direitos da Mulher: mais direitos, poderes e participação para as mulheres, 4. Anais... Brasília, DF, 2016. Disponível em: https://www.spm.gov.br/4cnpm/assuntos/Documentos/regulamento-interno-caderno-depropostas-4a-cnpm.pdf. Acesso em: 28 jan. 2019.

STOPPA, Edmur A.; ISAYAMA, Helder F. (Org.). Lazer no Brasil: representações e concretizações das vivências cotidianas. Campinas: Autores Associados, 2017.

TABET, Paola. La construcion sociale de I'negálité des sexes: des outils et des corps. Paris: L'Harmattan, 2004.

THOMPSON, E. P. Costumes em comum: estudo sobre a cultura popular tradicional. São Paulo: Companhia das Letras, 1998.

\section{Endereço dos Autores:}

Claudia Regina Bonalume

Oricolé/EEFFTO/UFMG

Av. Pres. Antonio Carlos 6627 - Pampulha

Belo Horizonte - MG - 31270-901

Endereço eletrônico: cbonalum@ @otmail.com

Hélder Ferreira Isayama

Oricolé/EEFFTO/UFMG

Av. Pres. Antonio Carlos 6627 - Pampulha

Belo Horizonte - MG - 31270-901

Endereço eletrônico: helderisayama@yahoo.com.br 